\title{
Modeling the impact of net primary production dynamics on post-disturbance Amazon savannization
}

\author{
MÔNICA C.A. SENNA ${ }^{1}$, MARCOS H. COSTA ${ }^{2}$, ERIC A. DAVIDSON ${ }^{3}$ and CARLOS A. NOBRE ${ }^{4}$ \\ ${ }^{1}$ Departamento de Análise Geoambiental, Universidade Federal Fluminense/UFF, \\ Av. Litorânea, s/n, Campus da Praia Vermelha, Instituto de Geociências, Sala 414, 24210-340 Niterói, RJ, Brasil \\ ${ }^{2}$ Departamento de Engenharia Agrícola, Universidade Federal de Viçosa/UFV, \\ Av. P.H. Rolfs, s/n, 36570-000 Viçosa, MG, Brasil \\ ${ }^{3}$ The Woods Hole Research Center, 149, Woods Hole Road, 02540-1644 Falmouth, MA, USA \\ ${ }^{4}$ Centro de Ciência do Sistema Terrestre, Instituto Nacional de Pesquisas Espaciais/INPE, \\ Rodovia Pres. Dutra, Km 39, 12630-000 Cachoeira Paulista, SP, Brasil
}

Manuscript received on July 23, 2012; accepted for publication on July 10, 2013

\begin{abstract}
Amazon tropical forests are being replaced by pasturelands and croplands, but they sometimes revert to regrowth forest when abandoned after a period of agricultural use. Research suggests that this secondary regrowth is limited by climate and nutrient availability and, using a coupled biosphere-atmosphere model, we investigated patterns in the regrowth of the Amazon rainforest after a full deforestation event, considering different types of nutrient stress. We found that, over a 50 year regrowth period, the reduction of precipitation caused by large-scale deforestation was not sufficient to prevent secondary forest regrowth, but this decrease in precipitation combined with nutrient limitation, due to logging and frequent fires, did indeed prevent forest regrowth in central and southern Amazonia, leading to a savannization. These results are concerning, as the northern Mato Grosso region has the highest clearing rate in Amazonia. The low resilience of the forest under nutrient stress indicates that a large scale disturbance could greatly expand the area suitable for cropland, accelerating forest disappearance.
\end{abstract}

Key words: Amazon, climate, deforestation, ecosystem model, net primary production, savannization.

\section{INTRODUCTION}

The Amazon tropical forest is one of the world's most important ecosystems, with a vital role for the world's biodiversity (Godoy et al. 1999, Prance et al. 2000, Dirzo and Raven 2003) and for the global carbon cycle (Clark et al. 2003, Clark 2004). Large areas of the Amazon forest have been deforested in recent decades by cattle ranchers, with an increasing role being played

Correspondence to: Mônica Carneiro Alves Senna

E-mail: monicasenna@id.uff.br by soybean plantation (Skole and Tucker 1993, Nepstad et al. 1999, 2006, Laurance et al. 2001, http://www.obt.inpe.br/prodes/). Deforestation degrades environmental services such as the maintenance of biodiversity, water cycling and carbon stocks (Foley et al. 2007). The future of the rainforests may be dependent on at least three positive feedbacks associated with deforestation.

The first feedback suggests that the reduction of precipitation after a large-scale deforestation might prevent an eventual forest regrowth (Shukla 
et al. 1990). The Amazon helps fuel the Hadley and Walker circulations in the tropical atmosphere. Several climate modeling experiments indicate that as deforestation increases, the subsequent reductions in evapotranspiration and atmospheric heating may weaken moisture recycling and deep convection over the Amazon, thus lowering precipitation (Shukla et al. 1990, Nobre et al. 1991, Costa and Foley 2000, Costa et al. 2007, Sampaio et al. 2007, Senna et al. 2009a).

The second feedback is related to the use of fire for land-clearing and for slash-and-burn agriculture, which is widespread in the Amazon (Nepstad et al. 2001, Zarin et al. 2005). Fires used for establishing cattle pasture or clearing areas for crops and in their management, often spread beyond the intended boundaries, increasing the susceptibility of forests to recurrent burning by removing trees, thereby allowing sunlight to penetrate the forest canopy, and increasing the fuel load on the forest floor (Nepstad et al. 1999, 2001, Aragão et al. 2008).

The third feedback is related to the effects of frequent burning on soil fertility and future dynamics of forest net primary production (NPP). A considerable amount of soil nutrients is lost to the atmosphere after repeated fire events, including $\mathrm{N}$ and $\mathrm{S}$ losses by volatilization and $\mathrm{P}$, $\mathrm{K}, \mathrm{Ca}$, and $\mathrm{Mg}$ losses by ash transport. Nutrients in the remaining ash might be lost by leaching to surface and groundwater (Kauffman et al. 1993, Mackensen et al. 1996, Sampaio et al. 2003). In fertilization studies (Gehring et al. 1999, Davidson et al. 2004, Silva et al. 2006), the secondary forest responded to application of $\mathrm{P}$ and $\mathrm{N}$, indicating that soil nutrient limitation may reduce the vegetation regrowth and the biomass accumulation rate. In addition, rates of secondary forest regrowth in Amazonia have been inversely correlated with the number of fires, and the biomass accumulation rate decreases $47 \%$ in areas with a history of frequent fires (Zarin et al. 2005). These studies indicate that nutrient limitation is a main factor in reducing the rate of forest regrowth. Nutrient stress also varies with forest age because the secondary forest regrowth increases the accumulation of total ecosystem N (Davidson et al. 2007). So, while the forest maturation has the capacity of rebuilding nutrient stocks, improving the environment for the forest regrowth, the reduction of forest regrowth rate makes this nutritional recuperation difficult.

Despite the evidence on the effects of changing precipitation, fire frequency, and nutrient status, we still do not know how these controls may interact to regulate the secondary forest regrowth and how these interactions may vary in different parts of Amazonia. Here, we investigate how the climate feedback and the nutrient feedback may affect the Amazon rainforest regrowth after a full deforestation. In a previous study (Senna et al. 2009a), we evaluated these feedbacks considering a gradual deforestation, however the nutrient limitation due to frequent fires was not considered. The fire feedback is not directly included in this study, but it is indirectly considered by a scenario that constantly penalizes the NPP of the regrowth forest. In this extreme scenario we want to represent the synergism between logging and fire used for land management in the region (Malhi et al. 2008). To address this issue, we used the fully coupled climate-biosphere model CCM3-IBIS with different initial land cover conditions and different types of nutrient stress.

\section{MATERIALS AND METHODS}

\section{MODEL DESCRIPTION}

In this study, we used the National Center for Atmospheric Research (NCAR) Community Climate Model version 3 (CCM3) (Kiehl et al. 1998) coupled with an updated version of the Integrated Biosphere Simulator (IBIS) (Foley et al. 1996, Kucharik et al. 2000). We refer to this coupled model as CCM3-IBIS (Delire et al. 2002). This is virtually the same core of the Lawrence Livermore National Laboratory (LLNL) model 
used in the Intergovernmental Panel on Climate Change (IPCC) AR4 simulations and in the Coupled Climate-Carbon Cycle Model Intercomparison Project ( $\mathrm{C}^{4} \mathrm{MIP}$ project), with the exception of our own tuning for the rainforest (Senna et al. 2009b). CCM3-IBIS can reproduce the bi-directional interactions between vegetation and climate, being indispensable for the study of biome distribution, ecosystem function, and climate feedbacks in the context of both global climate change and land use change (Foley et al. 2000).

CCM3 is an atmospheric general circulation model with spectral representation of the horizontal fields. It simulates the large-scale physics (radiative transfer, hydrologic cycle, cloud development, thermodynamics) and dynamics of the atmosphere. Here, we operated the model at a spectral resolution of T42 ( 2.81 ${ }^{\circ} \mathrm{X} 2.81^{\circ}$ latitude/longitude grid), 18 vertical levels, and a 15 -min time step. The oceans were represented by monthly averaged fixed sea-surface temperatures of the 1990s that served as boundary conditions for the atmosphere.

IBIS is a comprehensive model of terrestrial biospheric processes that represents the physical, physiological, and ecological processes occurring in vegetation and soils. IBIS simulates land surface processes, plant phenology and vegetation dynamics, and represents vegetation as two layers (trees and grasses). In IBIS a grid cell can contain one or more plant functional types that together comprise a vegetation type. Land surface physics and canopy physiology were calculated at the same time step used by CCM3. The plant phenology algorithm has a daily time step and the vegetation dynamics is solved with an annual time step. IBIS operated on the same T42 spatial grid as the $\mathrm{CCM} 3$, and with dynamic vegetation component enabled, so vegetation structure and biogeography changed in response to climate. Although the spatial resolution was relatively coarse, the explicit links between vegetation and climate represented a considerable step forward.
To date, IBIS does not contain a complete $\mathrm{N}$ cycle. Although soil $\mathrm{N}$ transformations are tracked in the soil biogeochemistry module reported in Kucharik et al. (2000), there are no soil N controls on vegetation productivity. Thus, we penalized the NPP of the regrowth forest directly, assuming that the nutrient limitation was caused by frequent fires before the beginning of the experiment. In this experiment, we considered two types of nutrient stress, fixed and dynamic. For a fixed nutrient stress, the forest NPP was $47 \%$ of the unlimited case, following the results for a young forest in Paragominas (eastern Amazonia) found by Davidson et al. (2004), and the results for sites with a history of recurrent fires found by Zarin et al. (2005). The fixed nutrient stress represented the synergism between logging and frequent fires. For a dynamic nutrient stress, the NPP was reduced according to an empirical relation that reflects a NPP decrease of $50 \%$ for trees biomass equal to zero, and no NPP decrease when the trees biomass reaches $10 \mathrm{~kg}-\mathrm{C} \mathrm{m}{ }^{-2}$ or more (typical values of a mature forest). This assumption reproduced the capacity of the secondary forest to rebuild nutrient stocks in mature stages (Davidson et al. 2007, Senna et al. 2009a), considering a smaller magnitude of human pressures than the previous scenario.

CCM3-IBIS was calibrated against Large Scale Biosphere-Atmosphere Experiment in Amazonia (LBA) tower results, and extensively validated against spatial fields of incident solar radiation, precipitation, land cover patterns, heterotrophic and root respiration, total NPP, aboveground NPP, wood NPP, leaf area index, and aboveground live biomass. The Amazon climate (annual mean and seasonality) was very well simulated for both incident solar radiation and precipitation. Average incident solar radiation and precipitation were within $7 \%$ and $5 \%$ of the observations, respectively. Average total NPP was within $5 \%$ and average aboveground NPP was within $2 \%$ of observations. Respiration rates and wood NPP were within 
$15 \%$ and $16 \%$ of the observations, respectively. Simulated aboveground live biomass was within $12 \%$ of Saatchi et al. (2007) estimates. For more details, refer to Senna et al. (2009b).

Climate models continue to have limitations (Stainforth et al. 2007), such as in their representation of clouds, which lead to uncertainties in the magnitude and timing, as well as regional details, of predicted climate change. Nevertheless, scientists are constantly working to further understand the climate system, and reduce the uncertainties IPCC (2007). The CCM3-IBIS ability to represent the main Amazon climate features increases our confidence that it represents the essential physical processes important for the simulation of future climate change.

\section{EXPERIMENT DESIGN}

The numerical experiment was designed to investigate the biosphere-atmosphere interaction of the Amazon rainforest regrowth under nutrient stress. The $\mathrm{CO}_{2}$ concentration was kept constant at 380 ppmv. The experiment evaluated different initial conditions (forest/pastureland) and different types of nutrient stress (dynamic/fixed). It was divided in four 50-year long simulations, with three ensembles each:

F: initial condition forest and no nutrient limitation (control run);

P: initial condition pasture and no nutrient limitation;

PND: initial condition pasture and with a dynamic nutrient limitation;

PNF: initial condition pasture and with a fixed nutrient limitation.

\section{RESULTS}

\section{LAND COVER PATTERNS}

The simulated land cover chronosequence with different initial conditions and different types of nutrient stress is illustrated in Figure 1. In the F simulation the Amazon tropical evergreen forest remained stable through the 50 years of the experiment, except for a small part in southeast Amazonia that became tropical deciduous forest, regionally called cerradão. Vegetation in few pixels in the Brazil-Venezuela border and in northeast Amazonia was misrepresented due to precipitation underestimation in these areas. In the $\mathrm{P}$ simulation the secondary forest regrew rapidly in all deforested area and the land cover patterns were quite similar to the $\mathrm{F}$ simulation after 50 years, although the biomass of this secondary forest was much smaller than the one of the primary forest (more details in Section Trees Biomass). In the PND case the forest regrowth was incomplete and was delayed by $20-30$ years in much of the region. In contrast, the secondary forest was unable to regrow in most of the region in the PNF simulation. Analyzing the four simulations, three distinct regions were evident. In region 1, over Colombia and northwestern state of Amazonas, Brazil, the secondary forest regrew in all simulations. In region 2, central Amazonia north of $10^{\circ} \mathrm{S}$ (centralsouthern state of Amazonas), after 50 years of simulation, an evergreen rainforest regrew in the P simulation, the PND deforested region became a tropical deciduous forest and the PNF land cover changed from grassland to savanna (regionally called cerrado strictu sensu). Finally, in region 3, southern Amazonia below $10^{\circ} \mathrm{S}$ (northern state of Mato Grosso), after 50 years, the PND and PNF land cover became a savanna and a dense shrubland (regionally called campo sujo), respectively. Even with a more optimistic nutrient stress in the PND simulation, there was no regeneration of the forest over region 3. In PNF simulation, the future climate and NPP dynamics favored the expansion of savannas in most of the Amazon region. Oyama and Nobre (2003) have shown that two stable vegetation-climate equilibrium states are possible in the region, one corresponds to tropical forest, and the other equilibrium state corresponds to a land cover in which most of eastern Amazonia 
is covered by savannas. Below, we analyzed the major variables that describe the climate-vegetation interaction in these three regions. Over each region, the mean values of these variables were calculated considering six grouped grid cells under the respective numbers shown in Figure 1.
PRECIPITATION

The region 1 annual mean precipitation (Figure 2a) was very similar for all simulations; there were only a few differences among them in the first years, when the deforested cases (P, PND, and PNF) had a smaller precipitation. The mean simulated
Years

1

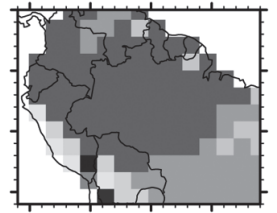

5

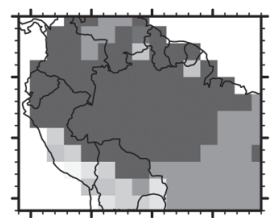

10

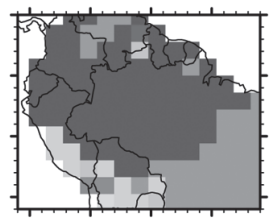

20

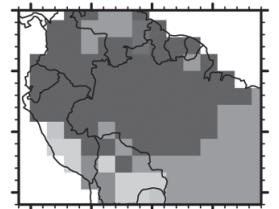

30

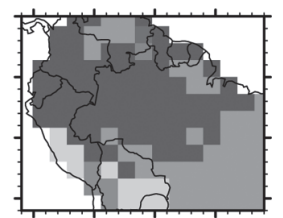

40

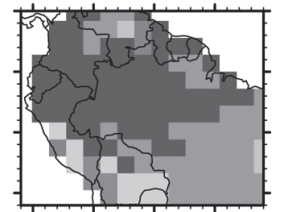

50

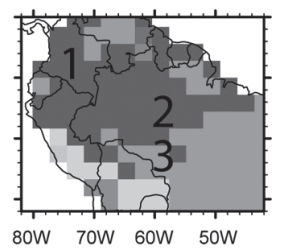

P
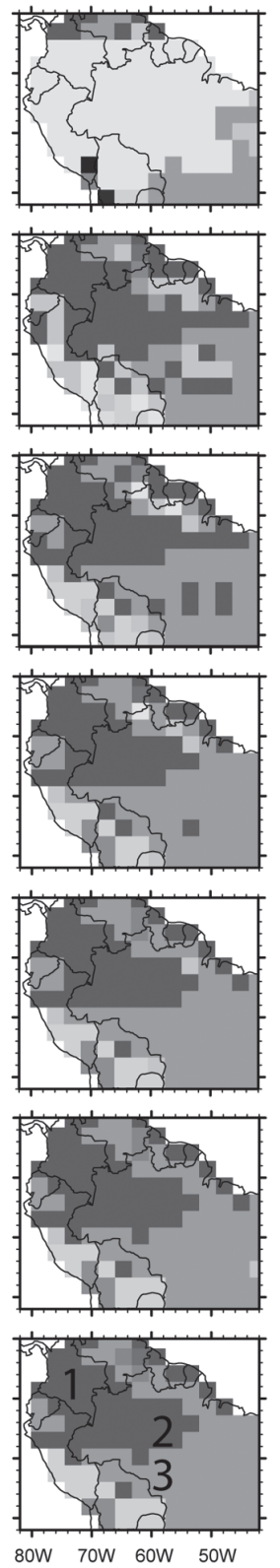

PND
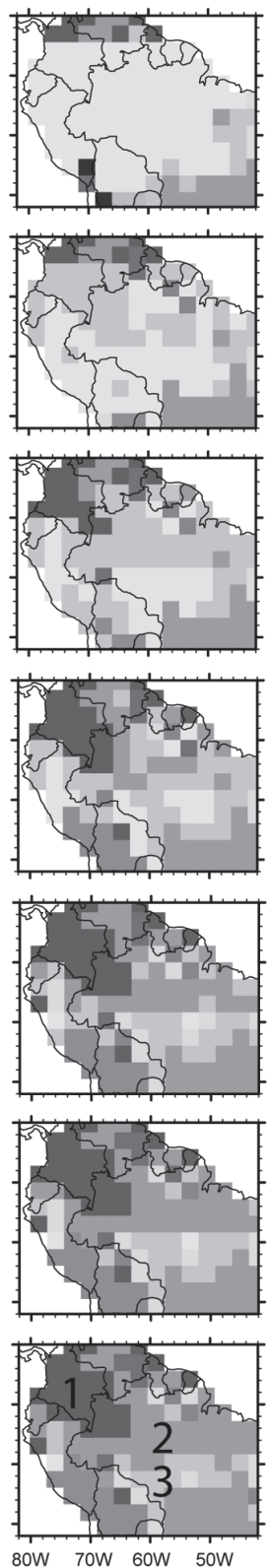

PNF
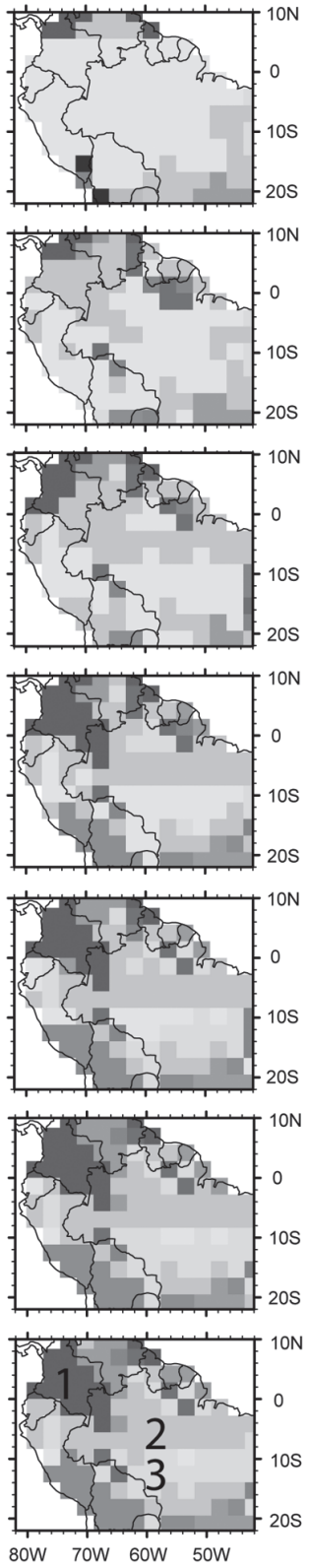

ice

desert

tundra

open shrubland

dense shrubland

grassland

savanna

mixed forest

boreal deciduous forest

boreal evergreen

forest

temperate deciduous forest

temperate evergreen conifer forest

temperate evergreen broadleaf forest

tropical deciduous forest

tropical evergreen forest

Fig. 1 - The simulated land cover chronosequence. The numbers 1, 2, and 3 represent the regions over Colombia and northwestern state of Amazonas in Brazil, over central Amazonia above $10^{\circ} \mathrm{S}$, and over southern Amazonia below $10^{\circ} \mathrm{S}$ (northern state of Mato Grosso), respectively. These regions were chosen because of the distinct simulated land cover after 50 years. 
precipitation for the 50 years was 8.8, 8.6, 8.8, and $8.3 \mathrm{~mm} \mathrm{day}^{-1}$ for F, P, PND, and PNF, respectively. This reflects that precipitation in this region was nearly independent of the land cover. $\mathrm{Fu}$ et al. (2001) and Li et al. (2006) showed that precipitation in the western Amazonia is a result of topographic moisture convergence forced by the east slope of the Andes of easterly trade winds from the Atlantic, largely dominant over land cover conditions. Over region 2 (Figure $2 b$ ), the annual mean precipitation of $\mathrm{F}$ simulation remained high, with an average of $8.4 \mathrm{~mm}$ day $^{-1}$ through the 50 years. The precipitation of $\mathrm{P}$ case was slightly lower in the first 10 years, and then reached the magnitude of $\mathrm{F}$ precipitation, with an average of $8.2 \mathrm{~mm}$ day $^{-1}$ through the 50 years. The precipitation in the PND and PNF cases was significantly lower. In PND, the precipitation increased slowly through the years and after 40 years it reached the F precipitation. This happens

(a)

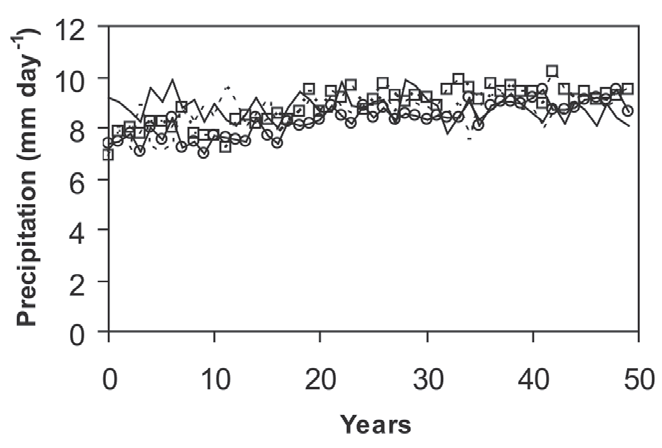

(b)

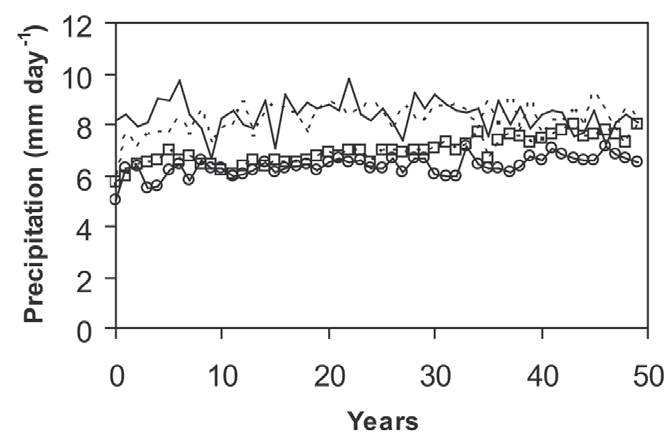

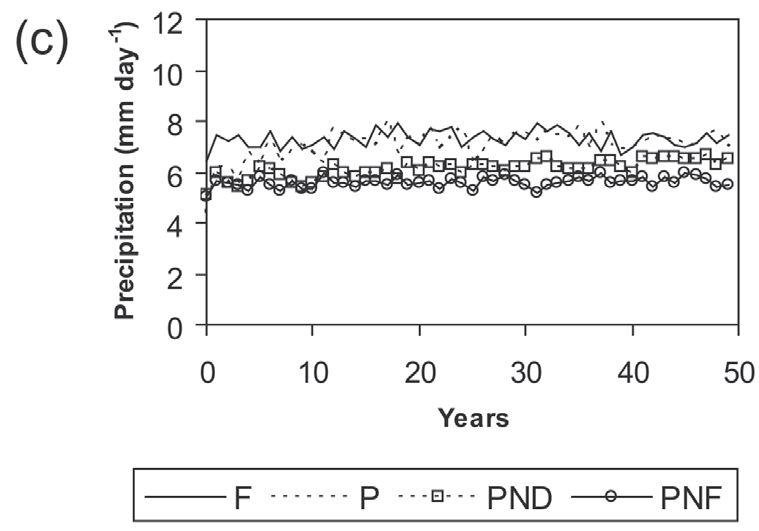

Fig. 2 - The simulated annual mean precipitation for (a) region 1 - Colombia and northwestern state of Amazonas, (b) region 2 - central Amazonia above $10^{\circ} \mathrm{S}$, and (c) region 3 - northern state of Mato Grosso. 


\section{Net PRIMARY PRODUCTION (NPP)}

Over region 1 (Figure 3a), the NPP of F simulation varied around $1.3 \mathrm{~kg}-\mathrm{C} \mathrm{m} \mathrm{m}^{-2} \mathrm{y}^{-1}$. The $\mathrm{P}$ case showed an initial period of intense growth, corresponding to the initial fast recovery of the secondary forest, with NPP reaching $2.0 \mathrm{~kg}-\mathrm{C} \mathrm{m}^{-2} \mathrm{y}^{-1}$, then decreasing and following the F NPP. The NPP of PND simulation increased until it reached the magnitude of $\mathrm{F}$ simulation after 30 years, and its mean value was $1.0 \mathrm{~kg}-\mathrm{C} \mathrm{m}^{-2} \mathrm{y}^{-1}$ through the 50 years. The PNF NPP never reached high levels, with an average of $0.7 \mathrm{~kg}-\mathrm{C} \mathrm{m}^{-2} \mathrm{y}^{-1}$ for the whole period. The region 2 NPP (Figure $3 b$ ) was very similar to the region 1 NPP for the F and P simulations, both with a 50 -yr mean value of $1.3 \mathrm{~kg}-\mathrm{C} \mathrm{m}^{-2} \mathrm{y}^{-1}$. The PND NPP increased during the simulation span, but did not reach the F and P NPP levels, with a 50-yr mean value of $0.7 \mathrm{~kg}-\mathrm{C} \mathrm{m}^{-2} \mathrm{y}^{-1}$. In the PNF simulation,

(a)

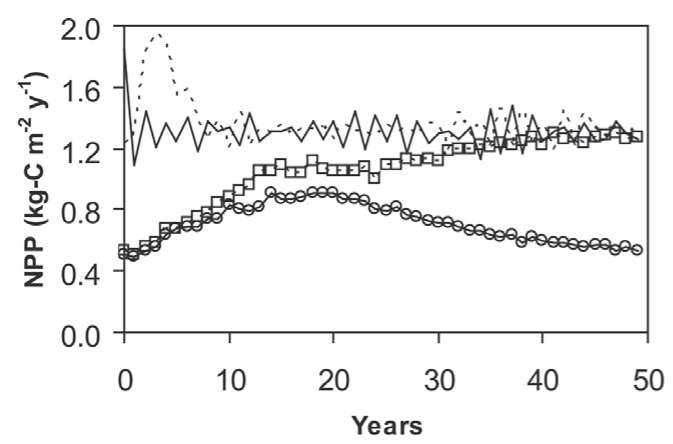

the NPP increased slightly throughout the years, with a $50-\mathrm{yr}$ average of $0.5 \mathrm{~kg}-\mathrm{C} \mathrm{m}^{-2} \mathrm{y}^{-1}$. Over region 3 (Figure $3 \mathrm{c}$ ), the $\mathrm{F}$ and $\mathrm{P}$ NPP remained together, although the average value was $1.0 \mathrm{~kg}-\mathrm{C}$ $\mathrm{m}^{-2} \mathrm{y}^{-1}$ throughout the entire period, lower than in the former regions, but still enough to build and maintain a rainforest. The PND and PNF NPP were significantly lower, with a 50-yr mean value of $0.3 \mathrm{~kg}-\mathrm{C} \mathrm{m} \mathrm{m}^{-2} \mathrm{y}^{-1}$, insufficient for a rainforest. A remarkable difference between regions 2 and 3 (southern Amazonas to northern Mato Grosso) was that while PND NPP increased with time in region 2 , it remained constant at a low level in region 3.

\section{TREES BIOMASS}

For simplification, trees biomass was uniformly initialized at $11.2 \mathrm{~kg}-\mathrm{C} \mathrm{m}^{-2}$ in all forest areas in the $\mathrm{F}$ simulation, and zero in P, PND and PNF

(b)

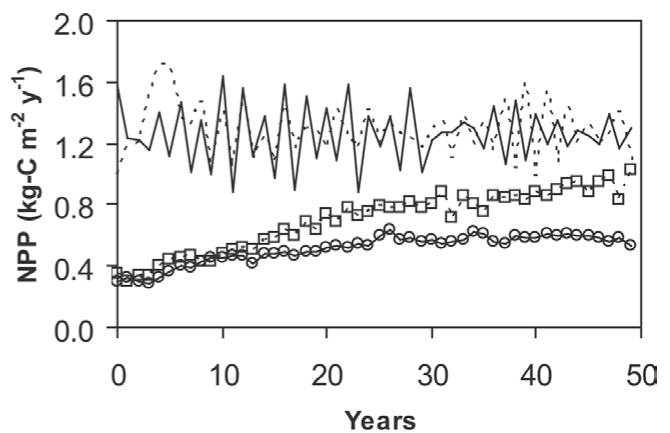

(c)

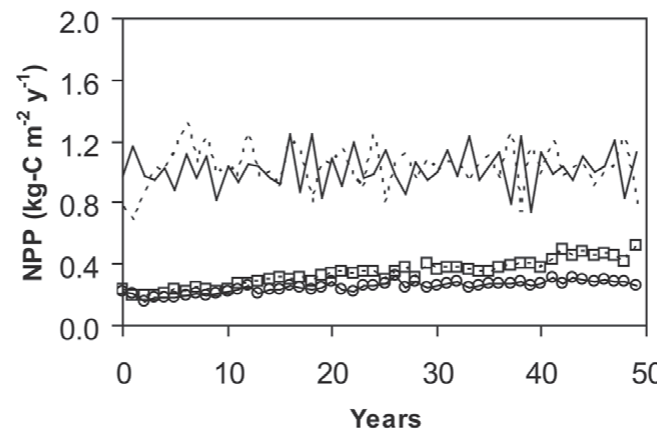

$-\mathrm{F} \cdots \cdots \cdot \mathrm{P} \cdots \boxminus \cdots \mathrm{PND} \longrightarrow \mathrm{PNF}$

Fig. 3 - The simulated annual mean net primary production for (a) region 1 - Colombia and northwestern state of Amazonas, (b) region 2 - central Amazonia above $10^{\circ} \mathrm{S}$, and (c) region 3 - northern state of Mato Grosso 
simulations. The simulated trees biomass over region 1 (Figure $4 \mathrm{a}$ ) for $\mathrm{F}$ case was nearly constant throughout the 50 years, with a mean value of 11.1 $\mathrm{kg}-\mathrm{C} \mathrm{m}^{-2}$. Trees biomass increased with time in all deforested cases over region 1 , and at the end of the simulated period, the $\mathrm{P}, \mathrm{PND}$, and PNF trees biomass were $10.3,8.8$, and $3.8 \mathrm{~kg}-\mathrm{C} \mathrm{m}^{-2}$, respectively. Over region 2 (Figure $4 \mathrm{~b}$ ), the trees biomass behavior was similar to region 1 , but the magnitudes were lower in the nutrient-limited cases. The trees biomass for the last simulated year were 10.8, 9.8, 5.5, and $1.8 \mathrm{~kg}-\mathrm{C} \mathrm{m}{ }^{-2}$ for F, P, PND, and PNF, respectively. Over region 3 (Figure $4 \mathrm{c}$ ), the $\mathrm{F}$ case trees biomass decreased with time, seeking a new equilibrium at $9.0 \mathrm{~kg}-\mathrm{C} \mathrm{m}^{-2}$. This occurred because in this region the land cover adjusted from an initialization of $100 \%$ evergreen rainforest to a mix of tropical evergreen forest and tropical deciduous forest, which was a more realistic representation of the current forest and its biomass than the uniform initialization (Figure 1). The trees biomass for $\mathrm{P}$ case increased throughout the 50 years of the experiment, reaching $7.9 \mathrm{~kg}_{-} \mathrm{C} \mathrm{m}^{-2}$. In the PND and PNF simulations, the increase of trees biomass was very small. PND reached $1.2 \mathrm{~kg}_{-} \mathrm{C} \mathrm{m}^{-2}$ and PNF reached $0.4 \mathrm{~kg}-\mathrm{C} \mathrm{m}^{-2}$ because in these simulations the secondary forest was unable to regrow. A contrast of the simulations in region 3 demonstrated how important the nutrient deficit could be for the regrowth of the secondary forest. In regions 1 and 2, the nutrient deficit just delayed the forest regrowth, but the region 3 secondary forest did not regrow under nutrient stress, at least during the 50 years of this experiment. (a)

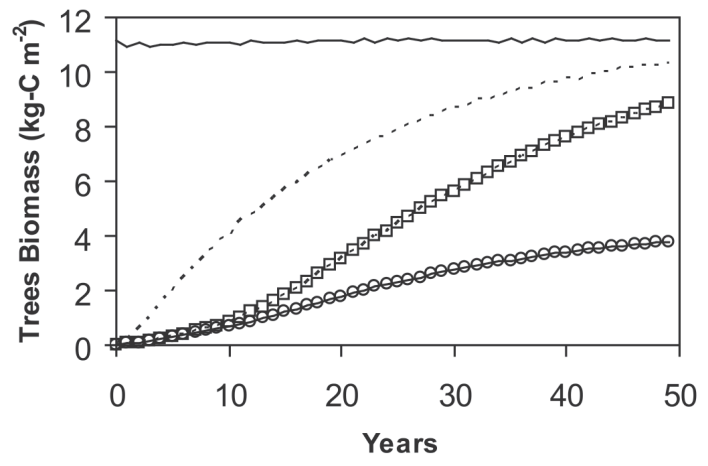

(b)

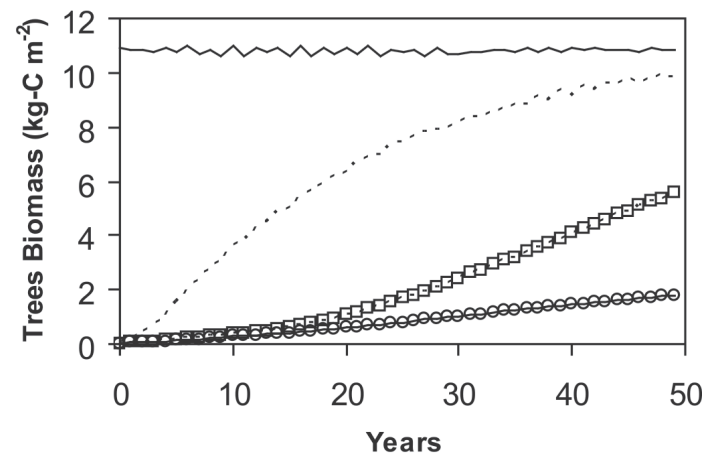

(c)

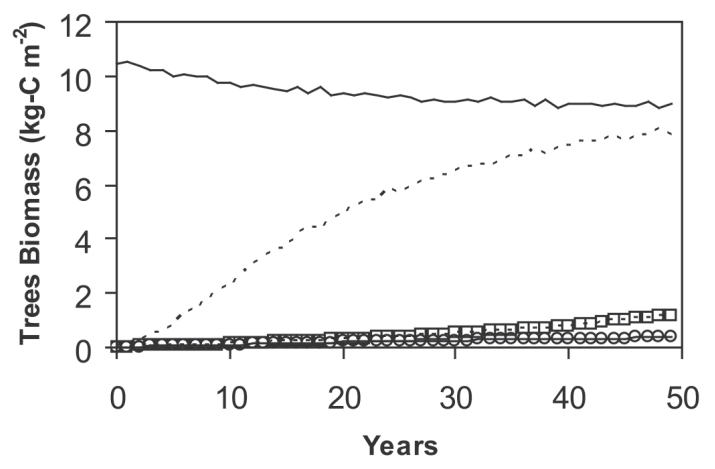

F $\cdots \cdots \cdot$ P $\cdots \boxminus \cdots$ PND $\longrightarrow$ PNF

Fig. 4 - The simulated annual mean trees biomass for (a) region 1 - Colombia and northwestern state of Amazonas, (b) region 2 central Amazonia above $10^{\circ} \mathrm{S}$, and (c) region 3 - northern state of Mato Grosso. 


\section{DISCUSSION AND CONCLUSIONS}

This study described the climate and soil nutrient feedbacks involved in the recovery of the Amazon rainforest after a large-scale deforestation. The secondary forest regrew faster in the deforested simulation without nutrient stress and its recovery occurred in all regions. Under nutritional limitation, however, different regions in the Amazon may respond differently, allowing the regrowth of the secondary forest back to a primary forest or leading to a savannization, as suggested by some studies (Nobre et al. 1991, Oyama and Nobre 2003, Hutyra et al. 2005).

The results presented here should be interpreted as an initial analysis of the biosphereatmosphere interactions in Amazonia. More studies focusing on soil fertility and biomass accumulation in secondary forests are needed, especially over central Amazonia and northern Mato Grosso, to considerably improve the scope of these modeling exercises and perform reliable projections of potential ecological disruption.

In the most optimistic scenario PND, which considered a small magnitude of human pressures after a full-scale Amazon deforestation, an evergreen rainforest would regrow only over northwestern Amazonia, a mixed forest would develop in central Amazonia, and a process of savannization would start over southern Amazonia. Considering the PNF scenario, where the anthropogenic forcing after the disturbance was large, an evergreen rainforest continued to regrow only over northwestern Amazonia, a savannization started over central Amazonia, and a dense shrubland developed in southern Amazonia.

The PND simulation was the most likely scenario, as long as we prevented disturbances such as fire to occur in the region. If this model represented the fire disturbance directly, probably these results would be more pessimistic in regions like the arc of deforestation, and probably would be more similar to PNF simulations. Fire volatilizes significant stocks of ecosystem N (Kauffman et al. 1995), preventing the secondary forest recovery and decreasing trees biomass (Botta and Foley 2002, Delire et al. 2003). Once burnt, the forest becomes more vulnerable to further burns because fire-induced tree death allows more sunlight to reach the forest interior, drying dead leaves and branches on the forest floor (Nepstad et al. 1999, 2001, Aragão et al. 2008). Besides, forests growing on nutrient-poor soils often develop thick roots above the mineral soil (Kauffman et al. 1988), and may be particularly vulnerable to fire-induced tree mortality since a substantial portion of the root system can be killed.

The land cover shift in the P, PND, and PNF scenarios would release around 7, 34, and $51 \mathrm{Pg}-\mathrm{C}$, respectively, including the initial deforestation emissions and the carbon sequestration during the 50 years of the experiment. Carbon emissions expected for each simulation were estimated by assuming that $85 \%$ of the carbon contained in deforested trees was released to the atmosphere (Soares-Filho et al. 2006), and the entire Amazonia was considered. This large-scale degradation could speed global warming, leading to a global climatic disruption (Cox et al. 2000, 2004).

We conclude that the simulated precipitation reduction caused by deforestation was not sufficient to prevent the secondary forest regrowth, as we can see in $\mathrm{P}$ simulation in all regions. However, when it is associated with a soil nutrient stress, the secondary forest may not regrow in southern Amazonia (in an optimistic scenario) where the precipitation rates are lower than in central and western Amazonia. With a fixed soil nutrient stress that combined forcings of deforestation and increased forest fire, an Amazon savannization process may take place in most of the region. In areas where the secondary forest regrew, the precipitation rates resumed normal values.

Furthermore, the vegetation dynamics and structure variables show how the ecosystem changes over time. In northwestern Amazonia, the 
final land cover was the same in all simulations, but the NPP of PNF case was lower than in the other simulations because of the fixed nutrient limitation. Simulated NPP fell within the limits of the observations for the biomes found in the three regions considered for all simulated scenarios (Zaks et al. 2007). Under fixed nutrient stress, trees biomass recovered slowly over northwestern Amazonia. However, the recovery of the forest, measured by these variables, was practically null over central and southern Amazonia, at least on the timescale of 50 years.

The simulated biosphere-atmosphere interactions indicated that the precipitation reduction caused by deforestation combined with soil nutrient limitations, due to logging and frequent fires, may prevent the regrowth of the rainforest in central and southern Amazonia. This is concerning, because southern Amazonia has elevated clearing rates, not only for pasture conversion but also for cropland expansion (Morton et al. 2006). Fire is the dominant land-clearing and pasture maintenance method throughout this region, and is practiced by most farmers and ranchers (Nepstad et al. 2001, Zarin et al. 2005). The low resilience of the forest under nutrient stress indicates that a large scale disturbance could greatly expand the area suitable for cropland, accelerating forest disappearance.

\section{ACKNOWLEDGMENTS}

This work was supported by NASA's Terrestrial Ecology Program as part of the LBA-ECO project (grants NCC5-687 and NNG06GE88A), Conselho Nacional de Desenvolvimento Científico e Tecnológico (CNPq, Brazil) and Coordenação de Aperfeiçoamento de Pessoal de Nível Superior (CAPES, Brazil).

\section{RESUMO}

A floresta tropical amazônica está sendo substituída por pastagens e lavouras, mas quando essas áreas são abandonadas após um período de uso agrícola, muitas vezes ocorre o recrescimento de uma floresta secundária. Pesquisas sugerem que esta floresta secundária é limitada pelo clima e pela disponibilidade de nutrientes e, usando um modelo acoplado biosfera-atmosfera, investigamos os padrões do recrescimento da floresta amazônica após um evento de desmatamento total, considerando diferentes tipos de estresse nutricional. Os resultados sugerem que ao longo de um período de recrescimento de 50 anos, a redução da precipitação causada pelo desmatamento em grande escala não foi suficiente para impedir o recrescimento da floresta secundária, mas essa diminuição da precipitação combinada a uma limitação de nutrientes, devido ao desmatamento e ao uso frequente do fogo, impediu a regeneração da floresta na região central e sul da Amazônia, levando a um processo de savanização. Estes resultados são preocupantes, pois o norte do Mato Grosso tem a maior taxa de desmatamento na Amazônia. A baixa resiliência da floresta sob estresse nutricional indica que uma perturbação de grande escala poderia expandir a área adequada para lavouras, acelerando o desaparecimento da floresta.

Palavras-chave: Amazônia, clima, desmatamento, modelagem de ecossistemas, produção primária líquida, savanização.

\section{REFERENCES}

ARAGÃo LEOC, MALHI Y, BARBIER N, Lima A, SHIMABUKURO Y, ANDERSON L AND SAATCHI S. 2008. Interactions between rainfall, deforestation and fires during recent years in the Brazilian Amazonia. Philos Trans R Soc London Ser B 363: 1779-1785.

BotTA A AND FOLEY JA. 2002. Effects of climate variability and disturbances on the Amazonian terrestrial ecosystems dynamics. Global Biogeochem Cycles 16(4) 1-11.

CLARK DA. 2004. Sources or sinks? The responses of tropical forests to current and future climate and atmospheric composition. Philos Trans R Soc London Ser B 359: 477-491.

Clark DA, Piper SC, KeEling CD and Clark DB. 2003. Tropical rain forest tree growth and atmospheric carbon dynamics linked to interannual temperature variation during 1984-2000. Proc Natl Acad Sci USA 100: $5852-5857$

COSTA MH AND FOLEy JA. 2000. Combined effects of deforestation and doubled atmospheric $\mathrm{CO}_{2}$ concentrations on the climate of Amazonia. J Clim 13: 18-34.

COSTA MH, YANAGI SNM, SOUZA PJOP, RIBEIRO A AND ROCHA EJP. 2007. Climate change in Amazonia caused by soybean cropland expansion, as compared to caused by pastureland expansion. Geophys Res Lett 34(7): 1-4. 
Cox PM, BetTs RA, COLlins M, HARris PP, HuntingFord C AND JONES CD. 2004. Amazonian forest dieback under climate-carbon cycle projections for the $21^{\text {st }}$ century. Theor Appl Climatol 78: 137-156.

Cox PM, BetTs RA, Jones CD, SPALl SA AND TotTerdell IJ. 2000. Acceleration of global warming due to carbon-cycle feedbacks in a coupled climate model. Nature 408: 184-187.

DAVIDSON EA ET AL. 2007. Recuperation of nitrogen cycling in Amazonian forests following agricultural abandonment. Nature 447: 995-998.

Davidson EA, CARVAlHo CJR, Viera ICG, Figueiredo RO, MOUTINHO P, ISHIDA FY, SANTOS MTP, GUERrERo JB, KALIF K AND SABÁ RT. 2004. Nitrogen and phosphorus limitation of biomass growth in a tropical secondary forest. Ecol Appl 14: 150-163.

Delire C AND Foley JA, Thompson S. 2003. Evaluating the carbon cycle of a coupled atmosphere-biosphere model. Global Biogeochem Cycles 17(1): 1-15.

Delire C, Levis SL, Bonan G, Foley JA, Coe MT and VAVRUS S. 2002. Comparison of the climate simulated by the CCM3 coupled to two different land-surface models. Clim Dyn 19: 657-669.

DIRZO R AND RAVEN PH. 2003. Global state of biodiversity and loss. Annu Rev Environ Resour 28: 137-167.

FOLEY JA ET AL. 2007. Amazonian revealed: forest degradation and loss of ecosystem goods and services in the Amazon Basin. Front Ecol Environ 5: 25-32.

Foley JA, LeVIS S, Costa MH, Cramer W AND Pollard D. 2000. Incorporating dynamic vegetation cover within global climate models. Ecol Appl 10: 1620-1632.

Foley JA, Prentice IC, RamankutTy N, LeVis S, Pollard D, Sitch S AND HAXELTine A. 1996. An integrated biosphere model of land surface processes, terrestrial carbon balance, and vegetation dynamics. Global Biogeochem Cycles 10: 603-628.

Fu R, Dickinson RE, Chen M And Wang H. 2001. How do tropical sea surface temperatures influence the seasonal distribution of precipitation in the equatorial Amazon? J Clim 14: 4003-4026.

Gehring C, Kanashiro M, Denich M and VleK PLG. 1999. Response of secondary vegetation in eastern Amazonia to relaxed nutrient availability constraints. Biogeochemistry 45: 223-241.

GodOY JR, PETTS G AND SALO J. 1999. Riparian flooded forests of the Orinoco and Amazon basins: a comparative review. Biodivers Conserv 8: 551-586.

Hutyra LR, Munger JW, Nobre CA, SALESKa SR, VIEIRA SA AND WOFSY SC. 2005. Climatic variability and vegetation vulnerability in Amazonia. Geophys Res Lett 32: 1-4.

IPCC. 2007. Climate Change 2007: The Physical Science Basis. Contribution of Working Group I to the Fourth Assessment Report of the Intergovernmental Panel on Climate Change, In: Solomon S, Qin D, Manning M, Chen Z, Marquis M, Averyt KB, Tignor M and Miller HL (Eds), Cambridge University Press, Cambridge, United Kingdom and New York, NY, USA.
Kauffman JB, Cummings DL, WaRd DE AND BabBitT R. 1995. Fires in the Brazilian Amazon: biomass, nutrient pools, and losses in slashed primary forests. Oecologia 104: 397-408.

Kauffman JB, Sanford JR RL, Cummings DL, Salcedo IH AND SAMPAIO EVSB. 1993. Biomass and nutrient dynamics associated with slash fires in neotropical dry forests. Ecology 74: 140-151.

Kauffman JB, Uhl C AND Cummings DL. 1988. Fire in the Venezuelan Amazon 1: Fuel biomass and fire chemistry in the evergreen rainforest of Venezuela. Oikos 53: 167-175.

KiEHL JT, HACK JJ, BONAN GB, BOVILlE BA, WiLLIAMSON DL AND RASCH PJ. 1998. The national center for atmospheric research community climate model: CCM3. J Clim 11: 1131-1149.

Kucharik CJ, Foley JA, Delire C, Fisher VA, Coe MT, Lenters JD, Young-Molling C, Ramankutty N, NORMAN JM AND GOWER ST. 2000. Testing the performance of a dynamic global ecosystem model: water balance, carbon balance, and vegetation structure. Global Biogeochem Cycles 14: 795-825.

Laurance WF, Cochrane MA, Bergen S, Fearnside PM, DELAMONICA P, BARBER C, D'ANGElo S AND FERnANDES T. 2001. Environment: the future of the Brazilian Amazon. Science 291: 438-439.

Li W, FU R AND DickinSON RE. 2006. Rainfall and its seasonality over the Amazon in the $21^{\text {st }}$ century as assessed by the coupled models for the IPCC AR4. J Geophys Res 111: D02111.

MACKENSEN J, HÖLSCHER D, KLINGE R AND FÖLSTER H. 1996. Nutrient transfer to the atmosphere by burning of debris in eastern Amazonia. For Ecol Manage 86: 121-128.

Malhi Y, Roberts JT, Betts RA, Killeen TJ, Li W AND NoBre CA. 2008. Climate change, deforestation, and the fate of the Amazon. Science 319: 169-172.

Morton DC, Defries RS, SHIMABUKURo YE, ANDERSON LO, ARAi E, Espirito-SANTO FDB, Freitas R AND MorisetTE J. 2006. Cropland expansion changes deforestation dynamics in the southern Brazilian Amazon. Proc Natl Acad Sci USA 103: 14637-14641.

Nepstad D, Carvalho G, Barros AC, Alencar A, Capobianco JP, Bishop J, Moutinho P, LefebVRe P, SILVA-JR UL AND PRINS E. 2001. Road paving, fire regime feedbacks, and the future of Amazon forests. For Ecol Manage 154: 395-407.

Nepstad DC, Stickler CM AND Almeida OT. 2006. Globalization of the Amazon soy and beef industries: opportunities for conservation. Conserv Biol 20: 1595-1603.

NEPSTAD DC ET AL. 1999. Large-scale impoverishment of Amazonian forests by logging and fire. Nature 398: 505-508.

Nobre CA, Sellers PJ AND ShuKla J. 1991. Amazonian deforestation and regional climate change. J Clim 4: 957-988.

OYAMA MD AND NOBRE CA. 2003. A new climate-vegetation equilibrium state for Tropical South America. Geophys Res Lett 30(23): 1-4. 
Prance GT, BeEntJe H, Dransfield J AND Johns R. 2000. The tropical flora remains undercollected. Ann Missouri Bot Gard 87: 67-71.

SAATCHI SS, Houghton RA, Alvalá RCS, SOARES JV AND YU Y. 2007. Distribution of aboveground live biomass in the Amazon basin. Global Change Biol 13: 816-837.

SAMPAIO FAR, FONTES LEF, COSTA LM AND JUCKSCH I. 2003. Nutrient and phytomass dynamics in a yellow Argissol under Amazonian tropical forest after burning and rice cultivation (in Portuguese with abstract in English). Rev Bras Cienc Solo 27: 1161-1170.

SAmpaio G, Nobre C, Costa MH, SATyamurty P, SoAresFilHo BS AND CARdoso M. 2007. Regional climate change over eastern Amazonia caused by pasture and soybean cropland expansion. Geophys Res Lett 34: 1-7.

Senna MCA, Costa MH, Pinto LIC, Imbuzeiro HMA, DINIZ LMF AND PIRES GF. 2009b. Challenges to reproduce vegetation structure and dynamics in Amazonia using a coupled climate-biosphere model. Earth Interactions 13: 1-28.

SEnNA MCA, Costa MH AND PIRES GF. 2009a. Vegetationatmosphere-soil nutrient feedbacks in the Amazon for different deforestation scenarios. J Geophys Res 114: D04104.

ShuKla J, Nobre CA AND Sellers PJ. 1990. Amazon deforestation and climate change. Science 247: 1322-1325.
Silva CEM, GONÇALVES JFC, FELdPAusch TR, LuizÃo FJ, MORAIS RR AND RIBEIRO GO. 2006. Nutrient use efficiency for pioneer species grown on abandoned pastures in central Amazonia (in Portuguese with abstract in English). Acta Amaz 36: 503-512.

SKOlE D AND TuCKer C. 1993. Tropical deforestation and habitat fragmentation in the Amazon - satellite data from 1978 to 1988 . Science 260: 1905-1910.

SoAres-Filho BS, Nepstad DC, CURran LM, CERQueIra GC, Garcia RA, Ramos CA, Voll E, McDonald A, LEFEBVRE P AND SCHLESINGER P. 2006. Modelling conservation in the Amazon basin. Nature 440: 520-523.

STAINFORTH DA, ALLEN MR, TREDGER ER AND SMITH LA. 2007. Confidence, uncertainty and decision-support relevance in climate predictions, Philos Trans R Soc London Ser A 365: 2145-2161. Doi: 10.1098/rsta.2007.2074.

ZAKS DPM, RAMANKUTTY N, BARFORD CC AND FOLEY JA. 2007. From Miami to Madison: Investigating the relationship between climate and terrestrial net primary production. Global Biogeochem Cycles 21: GB3004.

ZARIN DJ ET AL. 2005. Legacy of fire slows carbon accumulation in Amazonian forest regrowth. Front Ecol Environ 3: 365-369. 